\title{
Paperbound Books: Many Problems, No Solutions
}

The paperbound revolution began several decades ago with the replacement of animal glues by synthetic glues. Publishers, who now issue perfect bound editions in great quantities, have created serious binding problems for librarians. Answers to some of these problems lie in the development of new materials, machines, and techniques for use in the workshop of the library. If the work could be done in the library, some troublesome delays would be eliminated. Considering the rapid scientific and technological developments, it should be only a matter of time until someone provides the answers needed.

$\mathrm{T}$ HE PAPERBound Revolution of the past three decades has been received with varying degrees of enthusiasm by publishers, the public, and librarians. Publishers welcome the profits accompanying high volume sales. The low cost appeals to the public and librarians. Paperbounds are a mixed blessing, however, to librarians interested in durability as well as low cost, because they have encountered new problems created by certain characteristics of these books and magnified by the swiftly changing patterns of production in the publishing world.

There have always been books bound in paper or flexible covers, but the current boom began in England in 1935 with Penguin Books. When Pocket Books appeared in the United States in 1939 the boom was well on its way. For purposes of this paper, a paperbound book is any soft-cover monograph issued in more than fifty pages. This definition excludes periodicals. The Bowker Annual lists two broad types of paperbound books: "mass-market" and "other

Mr. Fristoe is Chief of Technical Processing, University of North Carolina. than mass-market." 1 There is no clear line between the two categories, but generally mass-market paperbounds are found on the racks in drugstores or newsstands and are cheaper than those usually sold by bookstores or published by scholarly organizations.

\section{Library Use of Paperbounds}

When paperbounds first appeared they were often issued as cheap reprints of popular hard-cover books, primarily fiction. This pattern has changed and they now encompass the whole spectrum of fiction and nonfiction. With the appearance of quality paperbounds the price range increased considerably, and such paperbounds currently may cost as much as $\$ 3.95$. At first paperbounds were little used by librarians, but this has also changed. Many libraries now buy them in single or multiple copies. They buy them with good reason -they are cheaper than hardbounds. The Bowker Annual indicates that in 1965 an adult trade paperbound cost

\footnotetext{
${ }^{1}$ The Bowker Annual of Library and Book Trade Information (New York, 1967), p. 46.
} 
438 / College \& Research Libraries • September 1968

TABLE 1

Adult Trade Books Sold Primarily through U.S. Booksellers

\begin{tabular}{|c|c|c|c|c|c|}
\hline Category & $\mathrm{YEAR}_{\mathrm{EAR}}$ & Volumes Sold & YEAR & Volumes Sold & Per Cent Change \\
\hline $\begin{array}{l}\text { Hardbound } \\
\text { Paperbound }\end{array}$ & $\begin{array}{l}1958 \\
1958\end{array}$ & $\begin{array}{r}32,298,000 \\
5,661,000\end{array}$ & $\begin{array}{l}1963 \\
1963\end{array}$ & $\begin{array}{l}40,213,000 \\
48,874,000\end{array}$ & $\begin{array}{r}24.2 \text { increase } \\
763.3 \text { increase }\end{array}$ \\
\hline
\end{tabular}

only one-third as much as a hardbound. ${ }^{2}$ Librarians often buy paperbounds for other compelling reasons. Many books are available only in this form. Some are published as paperbounds before appearing in hard cover, and some never appear in hard cover. Many hard-cover books go out of print and appear again only as paperbound reprints. Foreign titles are often available only as paperbounds. Of particular concern to the academic librarian is the fact that many publications of societies, associations, institutes, and similar scholarly organizations are offered only in paper covers.

Libraries sometimes use paperbound books to satisfy heavy, transient demand for current popular books. They may acquire multiple copies of some titles. There is often no effort to catalog these books. They are frequently shelved by broad categories on drugstore-type display racks. Circulation methods vary but are often quite informal. When they wear out or are no longer in demand, the library may then acquire durable hard-cover editions of the same titles. Other libraries add paperbounds to their permanent collections. When this occurs the books must be cataloged and prepared for long-time use. To serve this purpose the books must be reasonably durable, but the cost of rebinding should be modest. The expense of rebinding

2 Ibid., p. 53. has always been important to libraries and, in view of the changing patterns in the publishing world, it deserves the consideration of both librarians and the book trade at this time.

\section{Changing Patterns}

Broad acceptance of the paperbound book has brought significant changes in numbers of volumes sold and titles issued. The tables below consist of figures derived from the Book Trade Statistics sections of the 1960 through 1967 issues of the Bowker Annual.

Table 1 shows not only a rapid rate of growth in sales of paperbound books but also indicates that hardbounds have been overtaken in volumes sold. At the University of North Carolina library during the last seven months of 1966, 29.6 per cent of all books acquired were in paper covers. During the same period in 1967 the figure had risen to 46.7 per cent. Total acquisitions for 1967 meanwhile rose 38.4 per cent. An additional count of current acquisitions made during a two-week period in March 1968, showed that 23.7 per cent of all domestic acquisitions were paperbounds.

It is interesting to note that during the same period of time, the proportionate increase in sale of technical, scientific, and professional books was 73.9 per cent.

Statistics of foreign titles imported

TABLE 2

Technical, Scientific, and Professional Books Sold in U.S.

\begin{tabular}{l|c|c|c|c|c}
\hline \hline Category & Year & Volumes Sold & Year & Volumes Sold & Per Cent Change \\
\cline { 2 - 6 } All types & 1958 & $23,801,000$ & 1963 & $41,391,000$ & 73.9 increase \\
\hline
\end{tabular}


TABLE 3

Foreign Book IMports Distributed in the U.S.

\begin{tabular}{|c|c|c|c|c|c|}
\hline Category & YEAR & Titles & YeAR & Titles & Per Cent Change \\
\hline All types & 1959 & 1,900 & 1960 & 2,158 & 13.5 increase \\
\hline$"$ & 1960 & 2,158 & 1961 & 1,568 & 27.3 decrease \\
\hline$"$ & 1961 & 1,568 & 1962 & 2,051 & 30.8 increase \\
\hline " & 1962 & 2,051 & $1963^{\circ}$ & 2,161 & 5.3 increase \\
\hline$"$ & $1964^{*}$ & 4,797 & 1965 & 4,670 & 2.6 decrease \\
\hline & 1965 & 4,670 & 1966 & 6,347 & 35.9 increase \\
\hline
\end{tabular}

- In 1964 Publisher's Weekly changed its method of counting imports and it is not now possible to compare figures for 1963 and 1964 .

show considerable fluctuation during the eight-year period represented in Table 3. From 1964 to 1966 the number of titles increased by more than a third. No figures are available for a comparison of foreign hard- and soft-cover imports. A tally of books received at the University of North Carolina library for a two-week period in March 1968, revealed that 49.8 per cent of foreign imports were paperbounds.

Perhaps the most striking change occurs in Table 4, where non-mass-market titles increased by 1967.7 per cent during a ten-year period while mass-market titles increased by only 80.07 per cent. A change in this trend may be indicated by the very modest increase in non-mass-market titles from 1965 to 1966.

\section{How Paperbound Books Are Bound}

Librarians today must manage ever increasing numbers of titles and a growing ratio of paperbound to hardbound books. This growth has brought serious new binding problems to librarians. The common paperbound is usually bound in large quantities by an edition binder. The method most frequently used is known as "perfect" binding. Such a binding does not require sewing, rounding, or backing. The pages are trimmed, the back is fanned and glued to the spine. Occasionally other methods of binding are used. In some paperbounds the pages are held together by wire staples and in others sewing and staples are used together. Common paperbacks usually appear with glued-on covers, cheap paper, narrow margins, and in non-standard size.

Publications of societies, associations, and other scholarly organizations differ frequently from the common paperbacks in form. They may have no covers, they may be issued in fascicules, or they may be larger than the common paperbacks. Often they are printed on a quality calendered paper; they may even appear in loose-leaf form. At times the only thing they have in common with conventional paperbacks is the lack of a hard cover.

Paperbound books may be rebound either at a commercial bindery or in the

TABLE 4

Paperbound Titles Issued by U.S. Publishers

\begin{tabular}{|c|c|c|c|c|c|c|}
\hline Category & YEAR & Titles & YEAR & Titles & Per Cen & T Change \\
\hline $\begin{array}{l}\text { Mass-market } \\
\text { Other than mass-market }\end{array}$ & $\begin{array}{l}1957 \\
1957\end{array}$ & $\begin{array}{r}1,114 \\
355\end{array}$ & $\begin{array}{l}1966 \\
1966\end{array}$ & $\begin{array}{l}2,006 \\
7,340\end{array}$ & $\begin{array}{r}80.07 \\
1967.7\end{array}$ & $\begin{array}{l}\text { increase } \\
\text { increase }\end{array}$ \\
\hline $\begin{array}{l}\text { Mass-market } \\
\text { Other than mass-market }\end{array}$ & $\begin{array}{l}1965 \\
1965\end{array}$ & $\begin{array}{l}2,349 \\
6,968\end{array}$ & $\begin{array}{l}1966 \\
1966\end{array}$ & $\begin{array}{l}2,006 \\
7,340\end{array}$ & $\begin{array}{r}14.6 \\
5.3\end{array}$ & $\begin{array}{l}\text { decrease } \\
\text { increase }\end{array}$ \\
\hline
\end{tabular}


library. The commercial binder can rebind in library binding or in cardboard covered with plastic or vinyl. Library binding is a type of binding designed to assure the strength and durability needed to withstand heavy library use. Unlike edition binding, where large quantities of a single title are bound by mass production techniques, library binding requires special attention to individual items varying in size and shape. In library binding the paper cover is ripped from the spine, the pages are sewn together, trimmed, rounded and backed, reinforced, and glued to a cloth- or buckram-covered case. The result is stronger and more durable than hardcover edition binding, but the cost is higher. Unfortunately, many paperbounds have such narrow margins they cannot be rebound in library binding.

Another type of commercial binding, commonly known as Permabind or Vinabind, is similar to perfect binding. Sewing is eliminated but other features are added. The covers are removed, pasted on cardboard, and cased. The case is covered with a thin sheet of plastic or vinyl through which the original cover can be seen. The result is an attractive, relatively durable book. This type of binding costs less than library binding, but it brings other problems with it. Large or heavy volumes tend to fall apart. Quality paperbounds and scholarly publications are often printed on calendered paper which does not accept even the new synthetic glues well. Loose pages are a common result. Binders using this method provide a guarantee, but a book with loose pages must be returned to the bindery to be replaced or rebound by the binder, and this takes the book out of use.

Some rebinding of paperbounds is done in libraries by means of simple techniques and cheap materials. This type of rebinding usually involves removing the cover, sewing, stapling, or glueing. A case is usually made from adhesive coated cloth, cardboard, and cloth hinges and this is glued or stapled to the book. The result is neither attractive nor very durable, but the work can be done quickly and the cost is low.

\section{When Paperbound Books Are Bound}

When a librarian buys a book in a hard-cover edition he can buy the book from the publisher or through a dealer. His decision is based on relative price and service offered by the publisher and dealer. When he buys a paperbound book for permanent addition to the collection he has an additional decision: he must decide when the book is to be rebound. The book can be rebound either before or after it reaches the library. Some dealers specialize in locating and rebinding paperbound books before shipping to the library. They usually take orders only for domestic mass-market or "quality" books. They will not normally take orders for non-trade paperbound books because there is little or no profit even when the order can be filled. Such material is difficult to locate, and the likelihood of failure is quite high. Book dealers make no money on books they fail to find.

Some dealers rebind paperbound books as part of blanket order arrangements with libraries. They obtain all titles issued by a particular publisher or published in a particular country, or in a certain language or subject area. They have all soft cover books rebound prior to delivery to the library. Dealers handling such blanket order arrangments do not have the problem of filling individual orders. They must, of course, screen the titles located, but this is not as difficult as trying to locate obscure sources of short-run paperbounds.

A curious new aspect of paperbounds has recently developed in England. Some English paperbounds now appear with the following notice on the back of the title page: "These books are sold subject to the condition that they shall 
not, by way of trade or otherwise, be lent, resold, hired out or otherwise circulated without the publisher's prior consent in any form of binding or cover other than that in which they are published and without a similar condition including this condition being imposed on the subsequent purchaser." This appears to be an effort by the publisher to increase the sale of the more expensive hard cover edition. A publisher can, of course, declare such a limitation in the use of his product, but ultimately the question must be decided in court. Publishers in the United States have not yet seen fit to follow the same path. Unfortunately many books first appear as paperbounds, and many of these may never be reprinted in hard cover form. When hard cover first editions go out of print, cheap paperbound reprints may be the only form available to librarians. Penguin Books is now producing a series of hard-cover Penguin Literary Editions for books which first appeared in soft covers. This is only a partial solution, and it is unlikely that many publishers will adopt it. It is certainly not an adequate solution for the problem of out-ofprint material. The librarian is at the mercy of the publisher who, quite naturally, will publish another edition only when he feels a profit will be made.

\section{Problems}

Several problems face the librarian who adds paperbound books to his permanent collection. An article in the January 30, 1967, Publisher's Weekly discussed many aspects of paperbound publishing and stressed increased sales, number of titles, and consumer demand. It did not acknowledge the existence of a library demand for these books. In 1956 academic libraries spent $\$ 17,407,000$ on books, but by 1965 the figure had risen to $\$ 76,836,398 .^{3}$ This trend will probably be adversely affected by conflicting demands of the Vietnam war, but the annual increase was larger than federal aid even in the fiscal year ending June 30, 1966. During that year total federal aid to academic libraries for library materials was only $\$ 8,200,000$, when the annual increase was $\$ 10,000,000 .^{4}$ No figures are available to show what proportion of academic book expenditures is spent on paperbounds, but it should at least be a factor to be considered by publishers. Many first editions appear only as "quality" paperbounds, and librarians would welcome the simultaneous appearance of these titles in hard and soft cover. The librarian who intends to put a paperbound book into service is concerned with durability. The publisher must keep his costs as low as possible in order to make a profit. Most of his customers are not concerned with durability. In effect, the publisher has passed the cost of binding on to the librarian.

When a paperbound book leaves the library for rebinding it may be out of service for as much as a month. In many instances, for one reason or another, the delay is even longer. If the book is cataloged before binding, the catalog cards cannot be filed in the catalog until the book is returned, and a special procedure must be established to delay the filing of the cards. An alternative is to delay the cataloging until the book has been bound; this too, may cause problems. The library must be prepared to accept occasional errors in the form of the author and title on the spine of the book, and the task of adding the call number has been shifted to the library. All of these add to the cost and lead to frustrations, but the librarian has little choice if he is to add the book to his collection. It appears that the library must find an internal solution. 


\section{Possible Solutions}

There is, unfortunately, no good solution to the problem of achieving durable binding at modest cost. Arthur Plotnik, in "The 'Hardpaper' Book," discusses the emergence of a new product "about midway between the hardbound and paperbound trade book-intermediate in price, appearance and durability -perfectly suited for those intermediate library needs where a paperback is not durable enough and a hardcover too costly." " The hardpaper book, as described by Mr. Plotnik, is a considerable improvement over the paperback, and is cheaper than the hard-cover book. Unfortunately, it is not perfectly suited for library use. Most of the products he

${ }^{5}$ Arthur Plotnik, "The 'Hardpaper' Book," Library Journal, XCI (May 15, 1966), 2407-12. describes are either perfect bindings in mylar plastic covered boards, library bindings, or "bind-it-yourself-kits." The latter appear to be a possible solution because the work can be done in the library, but these kits are not cheap and the result appears to be no more durable than the usual library product. These kits do not represent a major breakthrough.

Dealers may eventually accept orders for foreign and domestic scholarly paperbound books. At least one dealer has recently proposed to act as a central agency for paperbound titles of all publishers, commercial and nonprofit, foreign and domestic. Perhaps this is the beginning of a trend, and perhaps dealers may be induced to bind before delivery.

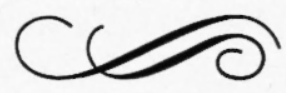

